\title{
Non-Invasive Glucometer of Automatic Measurement of the Glucose Level in Blood
}

\author{
Turapov U.U., Isroilov U.B., Guliev A.A., Muldanov F.R.
}

\begin{abstract}
This article aims to create a non-invasive method for determining glucose levels in diabetes to prevent diabetes. A non-invasive glucometer is aimed at creating a detection concept based on the biophysical parameters of biologically active points. When developing non-invasive fluorescence, experiments were carried out on healthy people and patients with two types of diabetes, confirmed by mathematical and statistical methods that correlate the amount of glucose in the blood and biophysical parameters at biologically active points.
\end{abstract}

Keywords: biofact active points, igloreflexotherapy, statistical processing, datasheet.

\section{INTRODUCTION}

In this article, using the electro-diagnostic method of igloreflexotherapy, J. Determining the amount of glucose in diabetes mellitus on the basis of electron biofuel points in the Riodoraku system of Nakatia, and finding mathematical connections among them and ultimately creating a mathematical model for noninvasive glucometer. The first step in building an adequate model is to get complete information on the change in glucose levels in diabetes mellitus, the statistical processing and analysis of data obtained from experiments on electro-diagnostic resistance detectors. We evaluated the biophysical parameters of biologically active points in the process of changing glucose or hyperglycemia in diabetes mellitus. In our subsequent work, we present a mathematical model of a non-invasive glucometer.

\section{RESEARCH METHODS}

Mathematical modeling, biochemical method for determining glucose in the blood, IRDU and EPTU methods, methods of pegression, software development, the theory of qualitative analysis of functional-differential equations.

Nowadays, human beings have argued that the models underway in the body as a cybernetic system give positive results, and that they need to be deepened and

Revised Manuscript Received on February 05, 2020.

* Correspondence Author

Turapov U.U.*, Department of Fundamentals of Informatic, Jizzakh Polytechnic Institute., Jizzakh, Uzbekistan. Email: ulugbek.turapov@mail.ru

Isroilov U.B., Department of Information Technology in Education, Jizzakh state pedagogical institute, Jizzakh, Uzbekistan. Email: isroilovub@gmail.com

Guliev A.A., Department of Fundamentals of Informatic, Jizzakh Polytechnic Institute., Jizzakh, Uzbekistan. Email: aalijon89@mail.ru

Muldanov F.R., Department of Radio Electronics, Jizzakh Polytechnic Institute., Jizzakh, Uzbekistan. Email: mmuldanov20@mail.ru

(c) The Authors. Published by Blue Eyes Intelligence Engineering and Sciences Publication (BEIESP). This is an open access article under the CC BY-NC-ND license (http://creativecommons.org/licenses/by-nc-nd/4.0/)

expanded in their research. The results of the research and literature review show that in the on-line mode of diagnostics and treatment of diabetes (TD) there is a wide range of igloreflexotherapy (IRT) methods to determine the amount of glucose in the blood and to identify the type of treatment therapies The main objective of this article is to develop an information support system, including functions. As you know, the human body is a complex system with a set of biofact active points(BFP). The processing of the numerical data, measured by biofuel points, requires the use of the theory of nontraditional headings. It is crucial to determine the amount of glucose in the blood based on IRT by creating mathematical, algorithmic, and software that evaluates the measured number of data and in the non-free environment. To date, the presence and role of glucose in the human body, the normal distribution of blood, and the presence of invasive and non-invasive glucose metabolites that monitor the progression of glucose levels in the TD, and the major drawbacks of these are the biophysics of the BFN using the IRT-based diagnostic equipment (BDE) measurement, the connection between the two parameters (EG in the blood glucose $+\mathrm{BFN}$ ) is eliminated from the point of view of medicine and cybernetics. The first task of the research is to create an automated neutral non-invasive glucometer mathematical model (ANGMM) in the body that determines the origin of diabetes mellitus in glucose levels in the blood. The use of IRP therapeutic procedures in iperglycemia in TD is a second global issue, which seeks to overestimate and decrease the BFPs electrical resistance (ER), with the creation of automated diagnostic and therapeutical complex (ADTC) system.

The stage of the clinical trials of ANGMM using the BFP (see Table 1) in J. Nakatani's Riodoraku method and the processing of the results obtained by mathematical statistics is as follows:

- carrying out experiments on measuring blood glucose content (MG \%) in the BFP in the ER and the biochemical method of the TD;

- statistical processing, datasheet, graphic, interval methods of analysis and processing using the spline methods;

- development of mathematical criteria for the differentiation process based on the amount of biophysical parameters in the informative BFP between healthy men and individuals 1 and 2 of TD.

Table I: Informative BFPs in the Riodoraku -system

\begin{tabular}{|l|l|l|l|}
\hline № & $\begin{array}{l}\text { The name of the } \\
\text { meridians }\end{array}$ & $\begin{array}{l}\text { Order of BFP } \\
\text { on meridians }\end{array}$ & $\begin{array}{l}\text { BFPs } \\
\text { Chinese name }\end{array}$ \\
\hline 1. & Lung & P-9 & Tay-yuan \\
\hline 2. & Big colon & Gi-4 & Xe- gu \\
\hline 3. & Stomach & E-42 & Chun -yan \\
\hline 4. & Pancreas & Rp-3 & Tay-bay \\
\hline
\end{tabular}




\begin{tabular}{|l|l|l|l|}
\hline 5. & Heart & C-7 & SHen-men \\
\hline 6. & Small colon & IG-4 & Van-gu \\
\hline 7. & $\begin{array}{l}\text { Urinary tract } \\
\text { system }\end{array}$ & V-64 & Szin-gu \\
\hline 8. & Liver & P- 3 & Tay-si \\
\hline 9. & Perikard & Mc-7 & Da-lin \\
\hline 10 & Three heaters & Tr-4 & Yan-chi \\
\hline 11 & Tufts & Vb- 40 & Suy-cuy \\
\hline 12 & Divorced & F-3 & Tay-chun \\
\hline
\end{tabular}

In order to solve the above problem, 1,2 out-of-kind patients and 1,170 healthy people were treated at the endocrinology department of the 1st Medical Clinic of the Tashkent Medical Academy (see Figure 2).

Methods used for the creation of ANGMM and APTM, their algorithms and CDS started at the Tashkent University of Information Technology (TUIT) and completed at Jizzakh Polytechnic Institute.

Table II.Information on the number 1.2 of the TD and the number of observations in healthy subjects

\begin{tabular}{|l|l|l|l|l|}
\hline Groups Class & $\begin{array}{l}\text { The } \\
\text { number }\end{array}$ & $\begin{array}{l}\text { Experience } \\
\text { the number }\end{array}$ & Time \\
\hline Healthy people & A & 80 & 120 & $8: 30$ \\
\hline $\begin{array}{l}\text { Type TD } \\
\text { (insulin-dependent } \\
\text { diabetic) }\end{array}$ & 5 & 200 & 750 & $8: 30$ \\
\hline $\begin{array}{l}\text { Type TD } \\
\text { (insulin-dependent } \\
\text { diabetic) }\end{array}$ & B & 90 & 880 & $8: 30$ \\
\hline $\begin{array}{l}\text { Total number of } \\
\text { views: }\end{array}$ & 370 & 1750 & \\
\hline
\end{tabular}

The following form of access was developed for experimental observations (see Table 3) and two observations were simultaneously performed on that table.

Table III: Form of Glucose Quantity in Blood and BFN EQ Experiment Form

\begin{tabular}{|l|l|l|l|l|l|}
\hline № & $\begin{array}{l}\text { The amount of } \\
\text { glucose in the } \\
\text { blood, mg,\% }\end{array}$ & $X_{1}$ & $X_{2}$ & $\cdots$ & $X_{n}$ \\
\hline 1 & $Y_{1}$ & $X_{11}$ & $X_{21}$ & $\cdots$ & $X_{n 1}$ \\
\hline 2 & $Y_{2}$ & $X_{12}$ & $X_{22}$ & $\cdots$ & $X_{n 2}$ \\
\hline$\cdots .$. & $\cdots$ & $\cdots$ & $\cdots$ & $\cdots$ & $\cdots$ \\
\hline$m$ & $Y_{m}$ & $X_{m 1}$ & $X_{m 1}$ & $\cdots$ & $X_{m n}$ \\
\hline
\end{tabular}

Based on the tables 1 and 2 above, the following formulas were utilized in the statistical processing of data for each class (in our scientific work divided into groups A, B, and B) to comply with mathematical statistics.

The mean arithmetic value of the parameters obtained (the amount of glucose in the blood and the ER in the BFP) is calculated using the formula

$M_{y}=\frac{1}{m} \sum_{i=1}^{m} y_{1} ; M_{x i}=\frac{1}{m} \sum_{i=1}^{m} X_{i j}$,

where , Y- is the amount of glucose in the blood;
The amount of ER obtained from the BFP in Xi.

We deduce the average arithmetic value from the formula below

$$
\begin{aligned}
& S_{y}=\sqrt{\frac{1}{m-1} \sum_{i=1}^{m}\left(Y_{i}-M_{y}\right)^{2}} ; \\
& S_{x y}=\sqrt{\frac{1}{m-1} \sum_{i=1}^{m}\left(X_{i j}-M_{x j}\right)^{2}} ;
\end{aligned}
$$

Using the formula (2), all parameter values serve as a formula evaluating the deviation of the arithmetic mean of this parameter. Parameters dispersion is calculated using the following formula

$D_{y}=\frac{1}{m-1} \sum_{i=1}^{m}\left(Y_{i}-M_{y}\right)^{2}$;

$D_{x j}=\frac{1}{m-1} \sum_{i=1}^{m}\left(X_{i j}-M_{x j}\right)^{2}$;

The value of the arithmetic mean of the error is determined by the following formula

$T_{y}=\sqrt{D_{y} / m} ; T_{x j}=\sqrt{D_{x j} / m}$

The algorithm and software for the statistical processing results using the formulas (1), (2), (3) and (4) above were created in $\mathrm{C}++$ programming languages. Graphic presentation of the mean arithmetic value of the ER in BFP in healthy people under average 24 years of age shows that the graphic representation of the mean arithmetic value of the ER in BFP is shown in Figure 1 below, and the mean age is 40 in healthy people And graphics in the 3.4 drawings by type 1,2 of TD. 

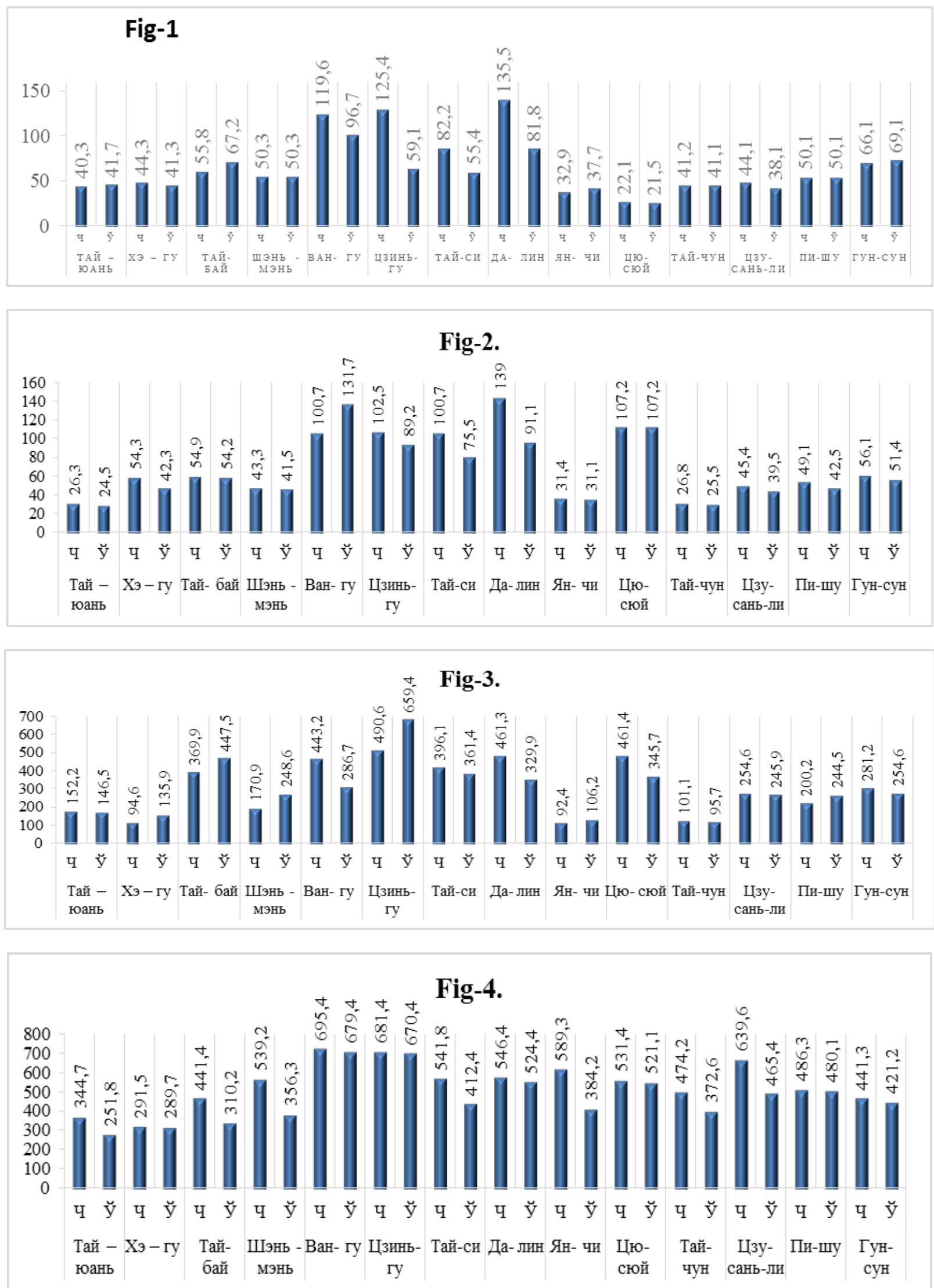

By using the interval method, the results of the ER in healthy BFPs were taken as the "normal corridor of healthy and mostly in the upper part, and are shown in Figures 5 and 6 people", on the basis of which scientific observation of the comparison of TD results in patients with type 1 outcome was carried out, below the ER "norm corridor" in some BFP less 


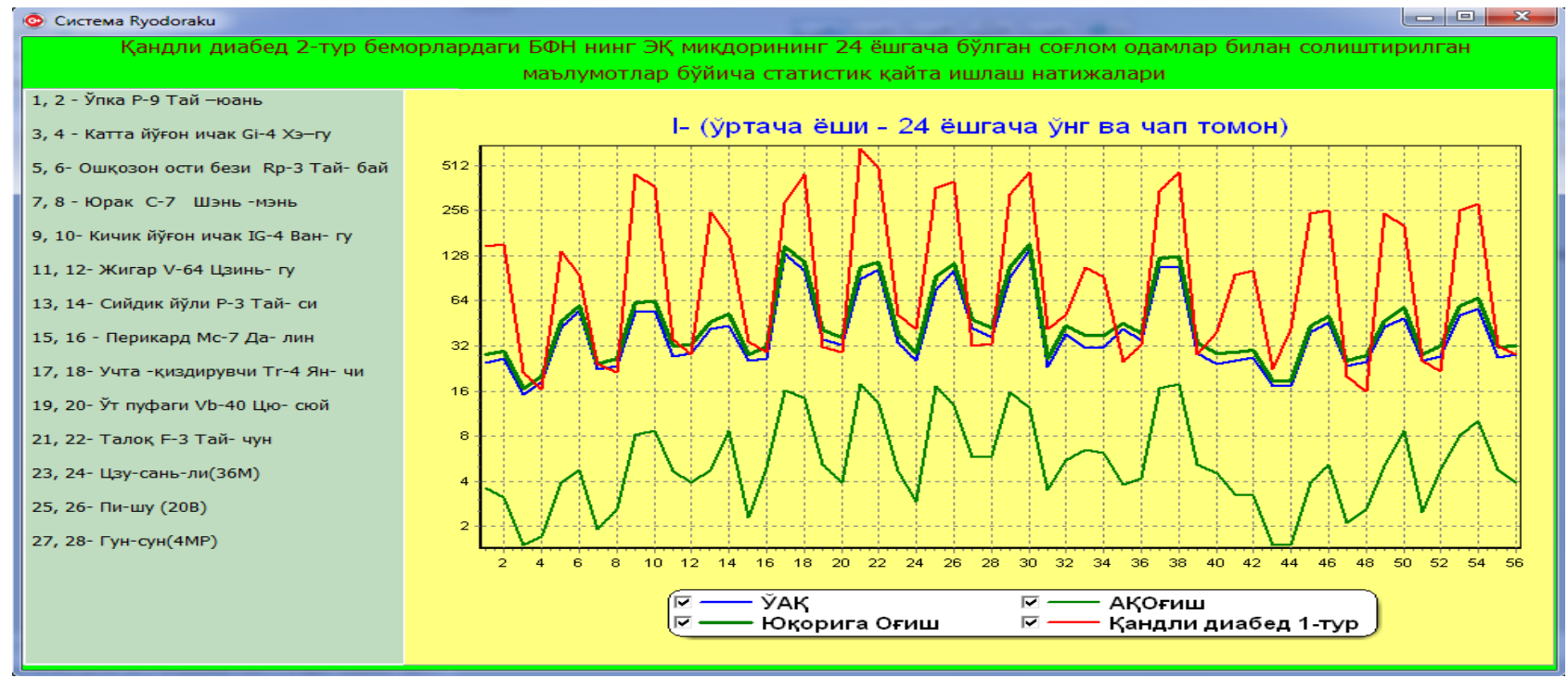

Figure 5. Comparison schedule of healthy men with type 1 and type 24 of TD.

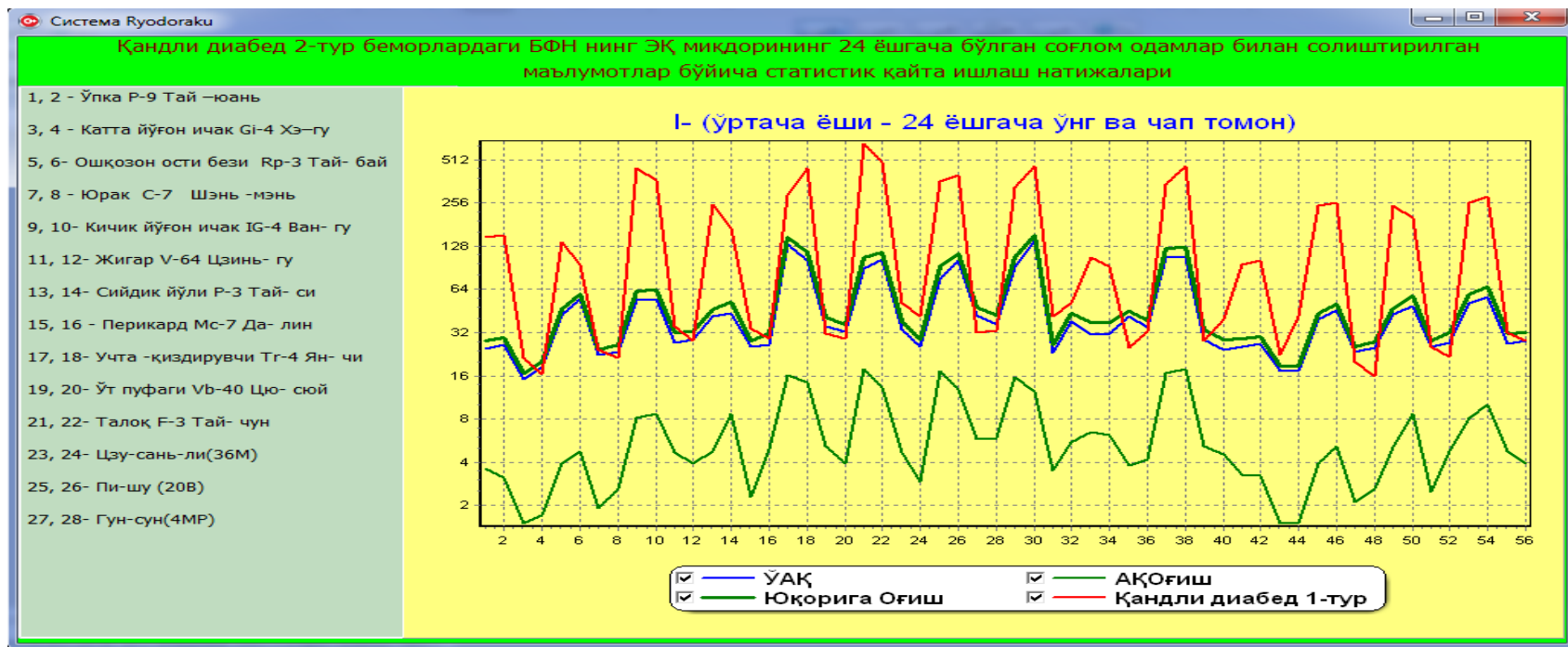

Figure 6. Results of the comparison between the 2 nd type of QD and the healthy 40 -year-old.

The statistical processing algorithm and its main window in $\mathrm{C}++$ are shown in Figure 7 below.

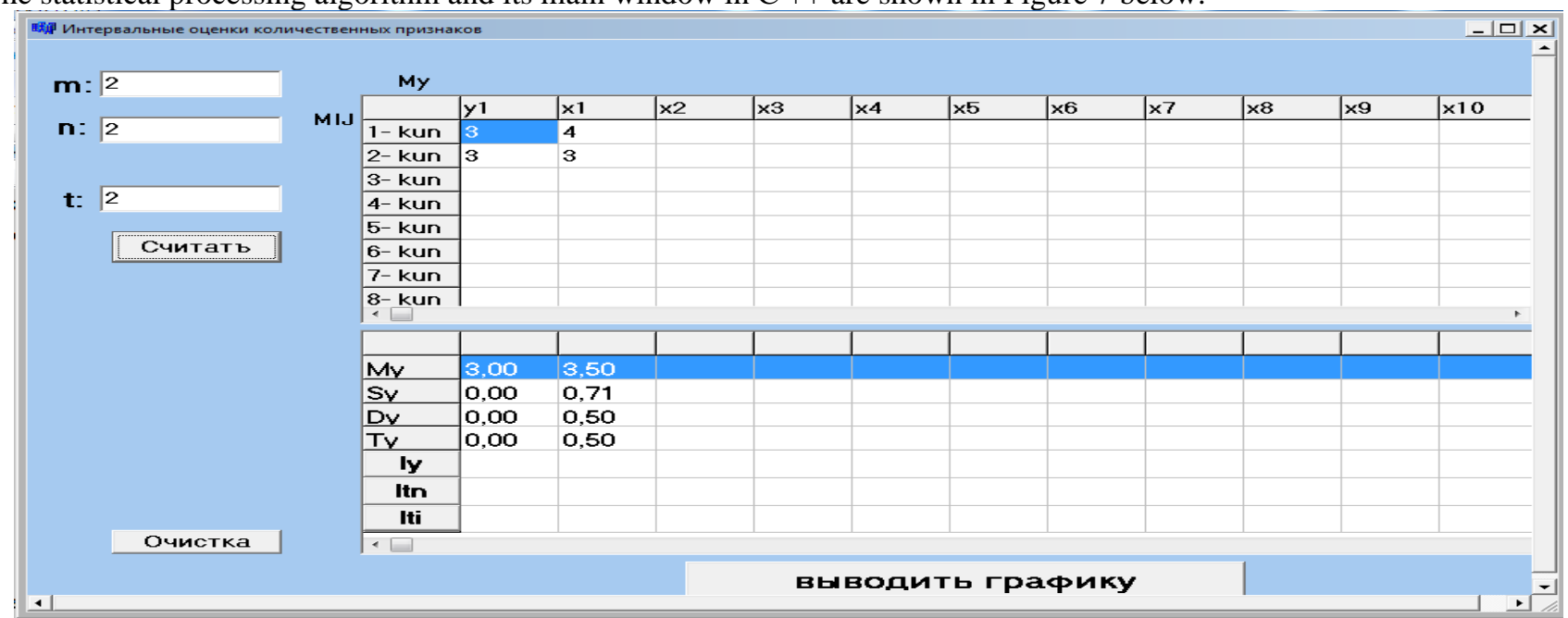

Figure 7. The main window of the Statistical Processing Program

The results of statistical processing using the formulas (1), (2), (3) and (4) above, graphic images from above in Figures 1, 2, 3, 4, and interval conclusions made in Figures 5 to 6 the relationship between glucose content and ER in BFPs is matched by mathematical laws (see Figure 8). and as a result, it has been proven that ANGMM models can be created. 


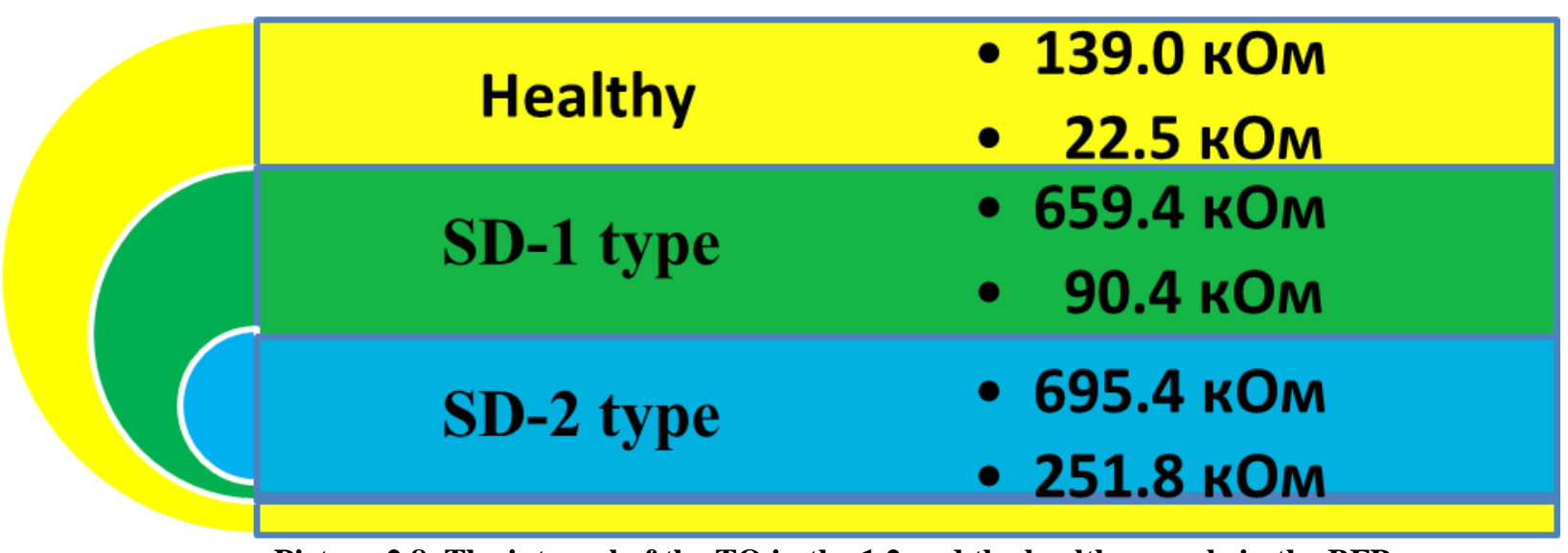

Picture 2.8. The interval of the TQ in the 1,2 and the healthy people in the BFP.

\section{RESULT AND DISCUSSION}

In summary, as a result of scientific experiments, the following results were determined:

1. Processing data based on computer-based computational experiments, the limits of vibrations of glucose and ER levels in healthy people, the appropriate minimum and maximum values of the values (ER in informative BFP 139.0 ), and it was recognized as a "Healthy Norm Corridor".

2. According to the vibration limits in the TD, when the glucose content in the blood was $6.5-21 \mathrm{mmol} / \mathrm{l}$, the ER in the informative BFN was changed from $16.4 \mathrm{kOm}$ to 695.4 $\mathrm{kOm}$.

3. Calculation experiments have shown that uncertainty in the intersection of the corridors of norms, ie, the emergence of an unstable environment, is based on the effectiveness of the theory of nontraditional collections.

4. The need for biofysical parameters of BFPs and healthy glucose levels in TD and healthy people, as a result of initial data processing, was scientifically justified in its mathematical models.

\section{CONCLUSION}

The following conclusions and conclusions were reached in the course of the study.

The principles of invasive and non-invasive glucometer equipment presented in the existing literature have been analyzed and the need for innovative ideas to be improved. A roadmap for ensuring that noninvasive glucometers work in a systematic information management environment has been identified to solve the problem. In order to provide online glucometers online, a software application has been developed that combines material knowledge and functions such as speed, versatility, noise reduction, early diagnosis, and treatment information flow management.

The relationship of the amount of glucose in the blood to electrical resistance at informative biologically active points was established by means of mathematical modeling and statistical statistical data processing. On the basis of model experiments, the limits of oscillation (norm corridor) of glucose and electrical resistance in healthy individuals were determined.

The uncertainty of the boundaries of the patients (type 1.2 diabetes) with the norm corridor was based on the uncertainty, ie the occurrence of an ambient environment. As a result of the data processing, an algorithmic and software was developed to determine the degree of deviation of the electrical resistance from the norm corridor in human body meridians, ie reprensively biologically active points, and to determine the diagnostic and pathological stages of the disease based on its quantitative values.

\section{REFERENCES}

1. Бабкин П.С., Зыков П.Н., Гусев Ю.Н., Утешева О.В. Способ измерения электрического сопротивления в биоактивных точках кожи // Открытые изобретения. - Москва, 1980. - №17.

2. Бойко Е.В., Мягков И.И., Вардинец Л.М. Изменение электрических параметров акупунктурных точек при сахарном диабете // В сб.: Актуальные вопросы экспериментальной и клинической эндокринологии. - Киев, 1982. - С. 101-102.

3. Вогралик В.Г., Вогралик М.В. Иглорефлексотерапия. - Горький, 1974.

4. Джаббаров К.А. Диагностическое значение исследований электропроводности и биопотенциалов кожи у больных сахарным диабетом // Азерб.мед.журнал. - Баку, 1983. - №9. - С. 28-32.

5. Дунаевская М.Б. Электрокожное сопротивление и чувствительность в зонах Захарина-Геда при заболеваниях органов в брюшной полости // Сов. медицина. - Москва, 1966. №3. - С. 51-61.

6. Дуринян Р.А. Методический и физический анализ проблемы точек, меридианов и энергии в рефлексотерапии. Медико-биологические и физико-технические аспекты. Саратов: Изд-во Саратовского университета, 1981. - $271 \mathrm{c.}$

7. Нечушкин А.И. и др. Определение функционального состояния канала по измерению электрокожного сопротивления в одной точке // В кн.: Иглорефлексотерапия. - Горький, 1974. - С. 22-25.

8. Подшибякин А.К. Значение активных точек кожи для эксперимента и клиники: Автореф. дис. докт. мед. наук. - Киев, 1960. - 31c

9. Портнов Ф.Г. Электропунктурная рефлексотерапия. - Рига Зинатне, 1987. - 352 c.

10. Huodo M.D. Ruodoraky treatment and objective approach to acupuncture // Amer.Jur. Acupuncture. - 1984. - Vol.12, №3. - p. 229-238.

11. Vin T.W. Avtomated approach to meridian-balensing and electro acupuncture instrumention // Amer.j.acupuncture. - 1977. - Vol.5. - p. 264.

12. Xianming H. // Akupuncture. - 1984. - Vol.3. - p.127-129.

13. Hyodo M.D.Ryodoraku treatment and objective approach to acupuncture. Osaka, 1975. - 140 p. 


\section{AUTHORS PROFILE}

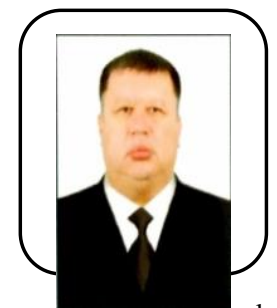

Turapov Ulugbek O'razkulovich, Candidate of Technical Sciences, Head of the Department of Information Technology at the Faculty of Electrical Engineering and Radio Electronics of the Jizzakh Polytechnic Institute. He was born on December 21, 1961 in Moltob village of Gallyaaral district of Jizzakh region. Higher education. In 1984, A.R. Beruniy graduated from the Tashkent Polytechnic Institute. Expert in the field of mathematical mouenny anu complex modeling of complex processes (biomedicine). In 1997-1991 he was a post graduate student at the Institute of Cybernetics of the Academy of Sciences of Uzbekistan, and on December 27, 1991 he defended his DSc He is currently working on a doctoral dissertation on the topic of "Mathematical and algorithmic software of blood composition identification using bioactive points of complex system in unclear environment". The author has published 5 textbooks, more than 100 scientific articles and theses, 1 textbook, 2 study guides, 5 software products.

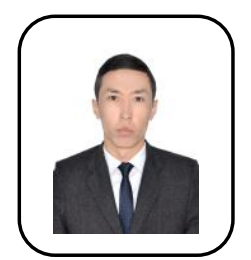

Isroilov Ulugbek Begali was born on August 24, 1992 in Gallyorol district of Jizzakh region. Nationality Uzbek, citizen of the Republic of Uzbekistan. In 1999, the city of Jizzakh. He entered the 1st class of the Pushkin Secondary School and finished the 9th grade in 2008. In 2008 he entered the Sayiljoy Academic Lyceum in Jizzakh and graduated in 2011 from the Lyceum. In 2011 he entered Jizzakh Polytechnic Institute and graduated in 2015. In the 2015-2016 academic year he worked as a teacher of computer science at the Jizzakh Professional College of Economics and Services. In 2016 - 2018, she completed her Masters degree at the Tashkent University of Information Technology. From September 5, 2018 she has been working as a teacher at the Department of Information Technology in Education at the Jizzakh State Pedagogical Institute. He is a doctoral (Phd) student of Jizzakh Polytechnic Institute on the specialty 05.01 .02 - "System analysis, management and data processing". The author has published seven scientific articles.

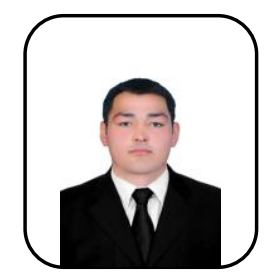

Guliyev Alijon Abdulhakimovich higher education, specialty "Computer systems and their software" 2014 (2012, specialty: Informatics and information technologies (vocational training). Graduated from the Tashkent branch of the Tashkent University of Information Technologies in 2014, Master's degree in Computer Systems and Software. He has been working as a senior lecturer at the Department of Information Technology. Over the past period A.A. Guliev has been actively involved in scientific conferences in the Republic and abroad. He has published more than theses and regularly participates in horseback riding. He also co-authored the course project on "Information Technology in Construction", "Information Technology in Technical Systems" and course work.

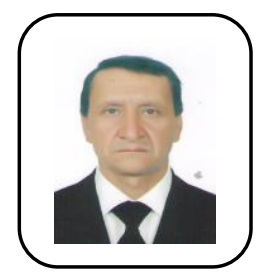

Muldanov Fayzi Riskulovich was born on August 25, 1970 in the village of Kangli, Zaamin district, Jizzakh region. Higher education. In 1996 he graduated from the Tashkent Electrotechnical Institute of Communications, majoring in electrical engineering. Since 2016 she has been working as a senior lecturer at the Department of Radio Electronics in Jizzakh Polytechnic Institute. Specialty 05.01 .04 - "Mathematical and software support of computers, complexes and computer networks" He is working on his doctoral dissertation on "Mathematical, software and technical support for the creation of robotic eye analyzer systems". He is the author of more than 10 scientific articles and thesis. 